\title{
Endoscopic ultrasound-guided fine-needle aspiration in the diagnosis of adrenal lesions
}

\author{
Rashmee Patila, Mel A. Ona ${ }^{b}$, Charilaos Papafragkakisc, Sushil Duddempudi ${ }^{b}$, Sury Anand ${ }^{b}$, Laith H. Jamil ${ }^{d}$ \\ Mount Sinai Health Systems, New York, New York; The Brooklyn Hospital Center, Academic Affiliate of The Icahn \\ School of Medicine at Mount Sinai, Clinical Affiliate of The Mount Sinai Hospital, Brooklyn, New York; MD Anderson \\ Cancer Center, Academic and Clinical Affiliate of the University of Texas, Houston, Texas; Cedars-Sinai Medical \\ Center, Los Angeles, CA, USA
}

Abstract

The use of endoscopic ultrasound-guided fine-needle aspiration (EUS-FNA) appears to be a safe and feasible means of confirming or excluding malignancy in the adrenal glands. EUS-FNA with biopsy of suspicious masses in either adrenal gland allows for assessment of these lesions while keeping complications relatively rare. The main advantages of EUS-FNA are that it can be done as an outpatient procedure, with good results, minimal morbidity, and a short hospital stay. Nevertheless, EUS-FNA of adrenal masses should be indicated only in selected cases, in which there is potential to either decrease unnecessary treatment or guide therapy in cancer patients by aiding in either staging of malignancy or treatment of recurrence.

Keywords Adrenal gland, endoscopic ultrasound, fine-needle aspiration, puncture

Ann Gastroenterol 2016; 29 (3): 1-5

\section{Introduction}

Ultrasonography (US), computed tomography (CT), magnetic resonance imaging (MRI), and the use of other advanced imaging techniques has led to increased detection of adrenal masses [1-3]. About 5\% of patients undergoing CT of the abdomen are found to have an adrenal lesion [4] and the incidence of an adrenal incidentaloma (detection of an otherwise unsuspected adrenal mass on imaging), ranges from 0.2 to $7 \%$ [5-7]. Most of these incidentally found lesions are non-functioning adenomas, but $2 \%$ are metastatic lesions.

About 75\% [1] of adrenal masses identified during staging of patients with cancer are metastatic lesions that could be metastases from malignancy involving mostly the lung,

Departments of anternal Medicine, Mount Sinai Health Systems, New York (Rashmee Patil); ${ }^{\mathrm{b}}$ Gastroenterology and Hepatology, The Brooklyn Hospital Center, Academic Affiliate of The Icahn School of Medicine at Mount Sinai, Clinical Affiliate of The Mount Sinai Hospital, Brooklyn, New York (Mel A. Ona, Sushil Duddempudi, Sury Anand); 'Advanced Therapeutic Endoscopy, MD Anderson Cancer Center, Academic and Clinical Affiliate of the University of Texas, Houston, Texas (Charilaos Papafragkakis); ${ }^{\mathrm{d} D i v i s i o n}$ of Digestive and Liver Diseases, Cedars-Sinai Medical Center, Los Angeles, CA (Laith H. Jamil), USA

Conflict of Interest: None

Correspondence to: Rashmee Patil, MD, $100010^{\text {th }}$ Ave, New York, NY 10019, USA, Tel.: +1 409656 6475, e-mail: rashmee84@gmail.com

Received 27 March 2016; accepted 26 April 2016;

Published online 20 May 2016

DOI: http://dx.doi.org/10.20524/aog.2016.0047 breast, stomach, kidney, skin, or lymphatic system [8-10]. The imaging techniques currently offered to differentiate a benign mass from a malignant one are not sensitive or specific enough. For this reason, patients with a high index of suspicion for malignancy are often referred for percutaneous biopsy [11-12].

Image-guided fine-needle aspiration (FNA) performed percutaneously using either US or CT has traditionally been the modality of choice for sampling of the adrenal glands. This technique, however, yields non-diagnostic samples in up to $14 \%$ of patients and is associated with adverse events in 0.412\% [13-16]. Endoscopic ultrasound (EUS)-guided FNA of either adrenal gland offers a less invasive and more accurate method for sampling the adrenals with a few side effects and complications [17]. The use of EUS-FNA is infrequently performed for the evaluation of adrenal lesions and there are few reported studies addressing the safety and feasibility of this technique, as shown in Tables 1 and 2. Few authors have recently summarized the use of EUS-FNA in the diagnosis of adrenal lesions. In the present review the indications, techniques, success rates, and complications reported with EUS-FNA of the adrenals are described.

\section{Materials and methods}

An extensive English language literature search was conducted using PubMed, Medline, Embase, and Google to identify peer-reviewed original and review articles using the keywords 'endoscopic ultrasound', 'fine-needle aspiration', 'adrenal', 'puncture, and 'EUS-FNA'. Only articles in humans 
Table 1 Patient characteristics in endoscopic ultrasound-guided adrenal fine-needle aspiration cases

\begin{tabular}{|c|c|c|c|c|}
\hline Study, (year) location [ref.] & Patients & Age (mean) & $\mathrm{M} / \mathrm{F}$ & Study design \\
\hline Puri et al (2015) India [37] & 21 & 56 & $14 / 7$ & Case series \\
\hline Martinez et al (2014) Indiana, USA [33] & 94 & 66 & $49 / 45$ & Case series \\
\hline Uemura et al (2013) Japan [18] & 11 & 70 & NM & Case series \\
\hline Sharma et al (2012) New York, USA [28] & 2 & $77 ; 44$ & $1 / 1$ & Case report \\
\hline Azhar et al (2011) Singapore [31] & 1 & 78 & $1 / 0$ & Case report \\
\hline Bang et al (2011) Alabama, USA [15] & 1 & 68 & $1 / 0$ & Case report \\
\hline Schuurbiers et al (2011) Netherlands [20] & 85 & 65 & $51 / 34$ & Case series \\
\hline Eloubeidi et al (2010) Alabama, USA [12] & 59 & 65 & $37 / 22$ & Case series \\
\hline Bodtger et al (2009) Denmark [8] & 40 & 63 & $20 / 20$ & Case series \\
\hline Eloubeidi et al (2009) Alabama, USA [30] & 1 & 49 & $1 / 0$ & Case report \\
\hline Haseganu et al (2009) Pennsylvania, USA [35] & 1 & 56 & $0 / 1$ & Case report \\
\hline Dewitt (2008) Indiana, USA [16] & 2 & 67 & $2 / 0$ & Case report \\
\hline Ang et al (2007) Singapore [29] & 4 & 76 & $4 / 0$ & Case series \\
\hline Dewitt et al (2007) Indiana, USA [6] & 38 & 61 & $21 / 17$ & Case series \\
\hline Gerke et al (2005) Iowa, USA [34] & 1 & 66 & $1 / 0$ & Case report \\
\hline Eloubeidi et al (2004) Alabama, USA [32] & 31 & 65 & $21 / 10$ & Case series \\
\hline Jhala et al (2004) Alabama, USA [36] & 24 & 62 & $18 / 6$ & Case series \\
\hline
\end{tabular}

were selected. The references of pertinent studies were manually searched to identify additional relevant studies. The procedural details, technical success rates, and complications were considered as part of the inclusion criteria. Search results yielded mostly small sample sized prospective or retrospective studies including case reports and case series.

\section{Results}

Seventeen original articles published were considered appropriate to be included in the review article. Of these, seven were case reports while the other ten were case series. The total number of patients included across all studies was 416. All cases have been summarized in Tables 1 and 2 .

\section{Demographics}

A total of 416 patients (mean age 65 years; 242 male) were included across all studies. Gender was not specified for the 11 patients included in the study by Uemura et al [18].

\section{Technique and technical success rate}

Linear EUS was performed in most patients. The left adrenal gland was visualized by transgastric imaging and transduodenal imaging was used for the right adrenal gland. To identify the left adrenal gland with the echoendoscope, the descending aorta was traced to the celiac trunk and gentle clockwise torque of the echoendoscope was applied to identify the left adrenal gland which appeared as a seagull-looking structure [12]. The right adrenal gland was identified from the second part of the duodenum through gentle withdrawal of the echoendoscope anterior to the right kidney while keeping counter-clockwise torque on the instrument. This would ultimately lead to visualization of the right adrenal gland in most cases. Though sometimes inaccessible and more difficult to visualize, the right adrenal gland could be seen with this gentle maneuvering of the echoendoscope and slight torque. A safe window often showed the liver on the right of the screen, the inferior vena cava on the left, and the right adrenal gland between them [14].

Once a right or left adrenal gland mass was identified, EUSFNA was performed by using a linear array echoendoscope. The size of the adrenal gland recorded in most studies was the maximal cross-sectional diameter of the gland. Average size of adrenal lesions across all studies was $25.9 \mathrm{~mm}$. EUS-FNA was performed using a 19-, 22-, or 25-gauge needle. Doppler imaging was used to confirm that there were no vascular structures along the path of the needle. After needle puncture of the adrenal gland, the stylet was removed. Depending on the operator, suction was applied or not applied using a vacuumcontaining syringe and if excess blood was present in the initial specimen, the operator attempted more passes with the same needle but without suction. This approach to sampling was uniform across all studies, and there was no maximum number of biopsy attempts allowed. Biopsy attempts were performed at the discretion of the gastroenterologist. The average number of biopsy attempts across all studies in our review was two. A transgastric approach was documented as performed in 
Table 2 Endoscopic ultrasound (EUS) and clinical features of adrenal masses undergoing attempted EUS-guided fine-needle aspiration

\begin{tabular}{|c|c|c|c|c|c|c|c|c|}
\hline $\begin{array}{l}\text { Study, (year) } \\
\text { location [ref.] }\end{array}$ & Location & $\begin{array}{l}\text { Diameter } \\
(\mathrm{mm})\end{array}$ & $\begin{array}{l}\text { Echo features } \\
\text { (n) }\end{array}$ & Approach & $\begin{array}{l}\text { No. } \\
\text { passes }\end{array}$ & Final diagnosis (n) & $\begin{array}{l}\text { Technical } \\
\text { success }\end{array}$ & Complications \\
\hline $\begin{array}{l}\text { Puri et al (2015) } \\
\text { India [37] }\end{array}$ & $\begin{array}{l}\text { Left }=18 \\
\text { Right }=3\end{array}$ & 16 & $\begin{array}{l}\text { Hypoechoic in } \\
\text { most }\end{array}$ & $\begin{array}{l}\mathrm{TG}=18 \\
\mathrm{TD}=3\end{array}$ & 4 & $\begin{array}{l}\text { Tuberculosis (10) } \\
\text { Malignancy (7) } \\
\text { Histoplasmosis (2) } \\
\text { Adrenal lipoma (2) }\end{array}$ & $21 / 21(100 \%)$ & None \\
\hline $\begin{array}{l}\text { Martinez et al (2014) } \\
\text { Indiana, USA [33] }\end{array}$ & $\begin{array}{l}\text { Left }=90 \\
\text { Right }=4\end{array}$ & 27.2 & Hypoechoic (66) & $\begin{array}{l}\mathrm{TG}=90 \\
\mathrm{TD}=4\end{array}$ & 3 & $\begin{array}{l}\text { Malignancy (25) } \\
\text { Benign adrenal tissue (60) } \\
\text { Non-diagnostic (9) }\end{array}$ & 94/94 (100\%) & None \\
\hline $\begin{array}{l}\text { Uemura et al (2013) } \\
\text { Japan [18] }\end{array}$ & $\begin{array}{l}\text { Right } \\
\text { and left }\end{array}$ & 25 & Hypoechoic (8) & $\begin{array}{l}\text { TG or TD } \\
\text { with } 19 \mathrm{G}\end{array}$ & 2 & $\begin{array}{l}\text { Malignancy (4) } \\
\text { Benign adrenal tissue (7) }\end{array}$ & $11 / 11(100 \%)$ & None \\
\hline $\begin{array}{l}\text { Sharma et al (2012) } \\
\text { New York, USA [28] }\end{array}$ & Right $=2$ & $60 \& 27$ & $\begin{array}{l}\text { Hypoechoic, } \\
\text { centrally cystic }\end{array}$ & $\begin{array}{l}\mathrm{TD}=2 \text { with } \\
22 \mathrm{G} \text { and } 25 \mathrm{G}\end{array}$ & 5 & $\begin{array}{l}\text { Metastatic lung } \\
\text { adenocarcinoma (1) } \\
\text { Metastatic breast } \\
\text { carcinoma (1) }\end{array}$ & $2 / 2(100 \%)$ & None \\
\hline $\begin{array}{l}\text { Azhar et al (2011) } \\
\text { Singapore [31] }\end{array}$ & Left & 21.2 & $\begin{array}{l}\text { Diffuse, } \\
\text { homogenous }\end{array}$ & $\begin{array}{l}\text { TG with } \\
22 \mathrm{G} \text { needle }\end{array}$ & NM & Histoplasmosis & $1 / 1(100 \%)$ & None \\
\hline $\begin{array}{l}\text { Bang et al (2011) } \\
\text { Alabama, USA [15] }\end{array}$ & Bilateral & $\begin{array}{c}\text { Right }=29 \\
\text { Left }=16\end{array}$ & $\begin{array}{l}\text { Irregular and } \\
\text { hypoechoic }\end{array}$ & $\begin{array}{l}\text { TG with } 22 \mathrm{G} \\
\text { TD with } 25 \mathrm{G}\end{array}$ & 1 & Metastatic melanoma & $1 / 1(100 \%)$ & None \\
\hline $\begin{array}{l}\text { Schuurbiers et al (2011) } \\
\text { Netherlands [20] }\end{array}$ & Left & 28.6 & NM & $\begin{array}{l}\text { TG with } \\
22 \mathrm{G} \text { needle }\end{array}$ & 3 & $\begin{array}{l}\text { Lung cancer metastasis (53) } \\
\text { Adrenal carcinoma (1) } \\
\text { Colon cancer metastasis (1) } \\
\text { Benign adrenal tissue (25) } \\
\text { Non-diagnostic (5) }\end{array}$ & $85 / 85(100 \%)$ & None \\
\hline $\begin{array}{l}\text { Eloubeidi et al (2010) } \\
\text { Alabama, USA [12] }\end{array}$ & $\begin{array}{l}\text { Left }=54 \\
\text { Right }=5\end{array}$ & 29.3 & Hypoechoic (49) & $\begin{array}{l}\mathrm{TG}=54 \\
\mathrm{TD}=5\end{array}$ & 3 & $\begin{array}{l}\text { Malignancy (22) } \\
\text { Benign adrenal tissue (37) }\end{array}$ & $59 / 59(100 \%)$ & None \\
\hline $\begin{array}{l}\text { Bodtger et al (2009) } \\
\text { Denmark [8] }\end{array}$ & Left & 30 & Hypoechoic (36) & $\begin{array}{l}\text { TG with } \\
22 \mathrm{G} \text { needle }\end{array}$ & 2 & $\begin{array}{l}\text { Malignancy (33) } \\
\text { Benign adrenal tissue (7) }\end{array}$ & $40 / 40(100 \%)$ & None \\
\hline $\begin{array}{l}\text { Eloubeidi et al (2009) } \\
\text { Alabama, USA [30] }\end{array}$ & Bilateral & $\begin{array}{c}\text { Left }=25 \\
\text { Right }=29\end{array}$ & NM & $\begin{array}{l}\text { TD \& TG with } \\
22 \mathrm{G} \text { needle }\end{array}$ & 2 & Histoplasmosis & $2 / 2(100 \%)$ & None \\
\hline $\begin{array}{l}\text { Haseganu et al (2009) } \\
\text { Pennsylvania, USA[35] }\end{array}$ & Left & 20 & Hypoechoic & TG with $22 \mathrm{G}$ & 2 & Metastatic SCLC & $1 / 1(100 \%)$ & $\begin{array}{l}\text { Adrenal } \\
\text { hemorrhage }\end{array}$ \\
\hline $\begin{array}{l}\text { Dewitt (2008) } \\
\text { Indiana, USA [16] }\end{array}$ & Right & 30 & $\begin{array}{l}\text { Mixed solid } \\
\text { and cystic; } \\
\text { Hypoechoic solid }\end{array}$ & $\begin{array}{l}\text { TD with } \\
22 \mathrm{G} \text { needle }\end{array}$ & 3 & $\begin{array}{l}\text { Pheochromocytoma (1) } \\
\text { Metastatic adenocarcinoma } \\
\text { of colon with necrosis (1) }\end{array}$ & $2 / 2(100 \%)$ & None \\
\hline $\begin{array}{l}\text { Ang et al (2007) } \\
\text { Singapore [29] }\end{array}$ & Left & 30.4 & $\begin{array}{l}\text { Hypoechoic (3) } \\
\text { Heterogeneous (1) }\end{array}$ & TG & 2 & $\begin{array}{l}\text { NSCLC metastasis (2) } \\
\text { Benign adrenal tissue (2) }\end{array}$ & $4 / 4(100 \%)$ & None \\
\hline $\begin{array}{l}\text { Dewitt et al (2007) } \\
\text { Indiana, USA [6] }\end{array}$ & Left & 24 & $\begin{array}{l}\text { Echo-poor (26) } \\
\text { Heterogeneous (5) } \\
\text { Echo-rich (2) } \\
\text { Unknown (5) }\end{array}$ & $\begin{array}{l}\text { TG with } \\
22 \mathrm{G} \text { needle }\end{array}$ & 3 & $\begin{array}{l}\text { Benign adrenal tissue (22) } \\
\text { Metastatic NSCLC (1) } \\
\text { Metastatic SCLC (1) } \\
\text { Metastatic melanoma ( } \mathrm{n}=1) \\
\text { Metastatic pancreatic } \\
\text { neuroendocrine tumor (1) } \\
\text { Metastatic esophageal ca (1) } \\
\text { Metastatic RCC (1) } \\
\text { Pheochromocytoma (1) } \\
\text { Non-diagnostic (9) }\end{array}$ & $38 / 38(100 \%)$ & None \\
\hline $\begin{array}{l}\text { Gerke et al (2005) } \\
\text { Iowa, USA [34] }\end{array}$ & Left & 18 & NM & $\begin{array}{l}\text { TG with } 19 G \\
\text { tru-cut needle }\end{array}$ & 1 & $\begin{array}{l}\text { Metastatic lung } \\
\text { adenocarcinoma }\end{array}$ & $1 / 1(100 \%)$ & None \\
\hline $\begin{array}{l}\text { Eloubeidi et al (2004) } \\
\text { Alabama, USA [32] }\end{array}$ & Left & 29 & NM & TG with $22 \mathrm{G}$ & 4.5 & $\begin{array}{l}\text { Malignancy (13) } \\
\text { Benign adrenal tissue (18) }\end{array}$ & $31 / 31(100 \%)$ & None \\
\hline $\begin{array}{l}\text { Jhala et al (2004) } \\
\text { Alabama, USA [36] }\end{array}$ & $\begin{array}{l}\text { Left=23 } \\
\text { Right=1 }\end{array}$ & 15 & NM & $\begin{array}{l}\mathrm{TG}=23 \\
\mathrm{TD}=1\end{array}$ & NM & $\begin{array}{l}\text { Malignancy (7) } \\
\text { Neoplasia (1) } \\
\text { Benign adrenal tissue (16) }\end{array}$ & $24 / 24(100 \%)$ & None \\
\hline
\end{tabular}


$359 / 416$ (86\%) patients while a transduodenal approach was documented as performed in 25/416 (6\%) cases. In 32 patients, the respective study did not document which approach was used. Further details regarding techniques of EUS-FNA of the adrenal gland are included in Table 2. The combined technical success rate was $100 \%$ in all case reports and series.

\section{EUS features of adrenal lesions}

Eleven of the seventeen studies included in this review reported that the majority of adrenal lesions were hypoechoic in nature as seen through echoendoscopic visualization. Although these lesions were more suspicious for malignancy based on this feature, the cytologic outcome did not support that the majority of lesions were malignant. For example, in Martinez et al [33] $66 / 94(70 \%)$ patients had an adrenal lesion with hypoechoic features, however $60 \%$ of cytology showed benign adrenal tissue.

\section{Complications}

No major complications were reported after EUS-FNA of the adrenal gland. Haseganu et al [30] reported a case of adrenal hemorrhage that occurred immediately after the procedure. The patient was admitted to the hospital and treated symptomatically, but remained hemodynamically stable.

\section{Discussion}

EUS-FNA is a novel method for diagnosing adrenal lesions. When compared with the traditional diagnostic modalities, it is not only more accurate than imaging studies such as CT or MRI, but also a very safe procedure with fewer complications than percutaneous biopsies [18-21]. When an adrenal incidentaloma is identified, the major concern is malignancy. According to guidelines from the National Institute of Health in 2002, malignancy is more likely in lesions $>4 \mathrm{~cm}$ in size [22]. In a recent study, a lesion with a diameter greater than $4 \mathrm{~cm}$ was shown to have $90 \%$ sensitivity for the detection of adrenocortical carcinoma [23]. For adrenal masses larger than $6 \mathrm{~cm}$ in diameter, most experts recommend resection [24].

The primary role of FNA biopsy is to differentiate between adrenal tissue and non-adrenal tissues (e.g. metastases or infection). Though no major complications were noted in our review of EUS-FNA, some potential complications from image or EUS-FNA include adrenal hematoma, abdominal pain, formation of an adrenal abscess, and tumor recurrence along the needle track [25]. Furthermore, pheochromocytoma needs to be ruled out prior to FNA of an incidental adrenal lesion to prevent the possibility of hemorrhage and hypertensive crisis [26]. Overall, the utility and indications for EUS-FNA of adrenal incidentalomas of small size is rare, given the unclear benefit and potential complications. For patients who do undergo the procedure, EUS-FNA of the left adrenal gland is a relatively simple procedure while EUS-FNA of the right adrenal gland is more challenging because the echoendoscope must be maneuvered carefully along vascular structure to visualize the gland. When compared with the 22-gauge needle, 25 -gauge needles are relatively more flexible and are preferred for performing trans-duodenal FNAs [27-31].

In summary, if EUS-FNA of the adrenal glands is available and there is a gastroenterologist on staff to perform this advanced procedure, it is a viable and minimally invasive alternative to adrenalectomy or percutaneous image-guided biopsy of the adrenal glands and may be considered by practitioners as it also has excellent yield for an accurate tissue diagnosis. As shown in our review, EUS-FNA of the adrenal gland had $100 \%$ technical success with no major complications and only one case of minor adrenal hemorrhage. This procedure can be done as an outpatient as is well-tolerated by patients. Likewise, results of tissue biopsy greatly affect patient management and direct further therapy. Results from FNA cytology for many patients in multiple studies included in our review showed the impact of EUS-FNA of the adrenal gland on final diagnosis of metastatic malignancy. For example, in patients with lung cancer, few studies included in this review evaluated the efficacy of EUS and EUS-FNA for the diagnosis of adrenal metastasis in patients with potentially resectable lung cancer [18]. As a result, EUS-FNA correctly diagnosed a patient with metastasis who was negative on both CT and positron emission tomography-CT. Whether a patient has a first-time malignancy diagnosis or recurrence, EUS-FNA can help guide therapy by providing information for staging and possibly avoiding further invasive procedures in palliative cases. EUS-FNA of the adrenal gland has been shown to be particularly useful in this regard in patients with lung cancer [32-37]. Future prospective, randomized, controlled studies that compare EUS with percutaneous US and/or CTguided FNA of the adrenal glands would be helpful to further delineate the indications and limitations of each technique.

\section{Concluding remarks}

EUS-FNA of the adrenal gland appears to be a safe and feasible procedure with good results, minimal morbidity and a short hospital stay in the cases reported in the literature. We recommend that EUS-FNA of adrenal masses should be indicated only in selected cases, in which the procedure may alter clinical management by either avoiding unnecessary treatment or helping with staging of malignancy or its recurrence. Further research should compare the benefits of percutaneous and echo-endoscopic approaches to adrenal FNA.

\section{References}

1. Lee MJ, Hahn PF, Papanicolaou N, et al. Benign and malignant adrenal masses: CT distinction with attenuation coefficients, size, and observer analysis. Radiology 1991;179:415-418.

2. Abrams HL, Siegelman SS, Adams DR, et al. Computed 
tomography versus ultrasound of the adrenal glad: a prospective study. Radiology 1982;143:121-128.

3. Krebs TL, Wagner BJ. MR imaging of the adrenal glad: radiologicpathologic correlation. RadioGraphics 1998;18:1425-1440.

4. Bovio S, Cataldi A, Reimondo G, et al. Prevalence of adrenal incidentaloma in a contemporary computerized tomography series. J Endocrinol Invest 2006;29:298-302.

5. Kuruba R, Gallagher SF. Current management of adrenal tumors. Curr Opin Oncol 2008;20:34-46.

6. DeWitt J, Alsatie M, LeBlanc J, et al. Endoscopic ultrasound-guided fine-needle aspiration of left adrenal gland masses. Endoscopy 2007;39:65-71.

7. Harisinghani MG, Maher MM, Hahn PF, et al. Predictive value of benign percutaneous adrenal biopsies in oncology patients. Clin Radiol 2002;57:898-901.

8. Bodtger U, Vilmann P, Clementsen P, et al. Clinical impact of endoscopic ultrasound-fine needle aspiration of left adrenal masses in established or suspected lung cancer. $J$ Thorac Oncol 2009;4:1485-1489.

9. Pantalone KM, Gopan T, Remer EM, et al. Change in adrenal mass size as a predictor of a malignant tumor. Endocr Pract 2010; 16:577-587.

10. Sharma KV, Venkatesan AM, Swerdlow D, et al. Image-guided adrenal and renal biopsy. Tech Vasc Interv Radiol 2010;13:100-109.

11. Lumachi F, Borsato S, Brandes AA, et al. Fine-needle aspiration cytology of adrenal masses in non-cancer patients: clinic-radiologic and histologic correlations in functioning and nonfunctioning tumors. Cancer 2001;93:323-329.

12. Eloubeidi MA, Black KR, Tamhane A, et al. A large single-center experience of EUS-guided FNA of the left and right adrenal glands: diagnostic utility and impact on patient management. Gastrointest Endosc 2010;71:745-753.

13. Arellano RS, Garcia RG, Gervais DA, et al. Percutaneous CTguided radiofrequency ablation of renal cell carcinoma: efficacy of organ displacement by injection of $5 \%$ dextrose in water into the retroperitoneum. AJR Am J Roentgenol 2009;193:1686-1690.

14. Eloubeidi MA, Beydoun M, Jurdi N, et al. Transduodenal EUSguided FNA of the right adrenal gland to diagnose lung cancer where percutaneous approach was not possible. J Med Liban 2011;59:173-175.

15. Bang JY, Hebert-Magee S, Varadarajulu S. Diagnosis of bilateral adrenal metastases secondary to malignant melanoma by EUSguided FNA. Am J Gastroenterol 2011;106:1862-1863.

16. DeWitt JM. Endoscopic ultrasound-guided fine-needle aspiration of right adrenal masses: report of 2 cases. $J$ Ultrasound Med 2008;27:261-267.

17. Tsitouridis I, Michaelides M, Stratilati S, et al. CT guided percutaneous ad- renal biopsy for lesions with equivocal findings in chemical shift MR imaging. Hippokratia 2008;12:37-42.

18. Uemura S, Yasuda I, Kato T, et al. Preoperative routine evaluation of bilateral adrenal glands by endoscopic ultrasound and fineneedle aspiration in patients with potentially resectable lung cancer. Endoscopy 2013;45:195-201.

19. Wu HH, Cramer HM, Kho J, et al. Fine needle aspiration cytology of benign adrenal cortical nodules. A comparison of cytologic findings with those of primary and metastatic adrenal malignancies. Acta Cytol 1998;42:1352-1358.

20. Schuurbiers OC, Tournoy KG, Schoppers HJ, et al. EUS-FNA for the detection of left adrenal metastasis in patients with lung cancer. Lung Cancer 2011;73:310-315.

21. Sood SK, Balasubramanian SP, Harrison BJ. Percutaneous biopsy of adrenal and extra-adrenal retroperitoneal lesions: beware of catecholamine secreting tumours! Surgeon 2007;5:279-281.

22. Young Jr WF. Clinical practice: The incidentally discovered adrenal mass. N Engl J Med 2007;356:601-610.

23. Angeli A, Osella G, Ali A, Terzolo M. Adrenal incidentaloma: an overview of clinical and epidemiological data from the National Italian Study Group. Horm Res 1997;47:279-283.

24. Grumbach MM, Biller BM, Braunstein GD, et al. Management of the clinically inapparent adrenal mass ("incidentaloma"). Ann Intern Med 2003;138:424-429.

25. Arellano RS, Harisinghani MG, Gervais DA, Hahn PF, Mueller PR. Image-guided percutaneous biopsy of the adrenal gland: review of indications, technique, and complications. Curr Probl Diagn Radiol 2003;32:3-10.

26. Casola G, Nicolet V, vanSonnenberg E, et al. Unsuspected pheochromocytoma: risk of blood-pressure alterations during percutaneous adrenal biopsy. Radiology 1986;159:733-735.

27. Dietrich CF, Wehrmann T, Hoffmann C, et al. Detection of the adrenal glands by endoscopic or transabdominal ultrasound. Endoscopy 1997;29:859-864.

28. Sharma R, Ou S, Ullah A, et al. Endoscopic ultrasound (EUS)guided fine needle aspiration (FNA) of the right adrenal gland. Endoscopy 2012;44(Suppl 2 UCTN): E385-E386.

29. Ang TL, Chua TS, Fock KM, et al. EUS-FNA of the left adrenal gland is safe and useful. Ann Acad Med Singapore 2007;36:954-957.

30. Eloubeidi M, Luz L, Crowe D, et al. Bilateral adrenal gland enlargement secondary to histoplasmosis mimicking adrenal metastases: Diagnosis with EUS-guided FNA. Diagnostic Cytopathology 2009;38:357-359.

31. Azhar J, Jacqueline H, Tony L, et al. Bilateral adrenal histoplasmosis: endoscopic ultrasound-guided fine needle aspiration as a method of diagnosis and assessment. Med J Malaysia 2011;66:504-506.

32. Eloubeidi M, Seewald S, Tamhane A, et al. EUS-guided FNA of the left adrenal gland in patients with thoracic or GI malignancies. Gastrointest Endosc 2004;59:627-633.

33. Martinez M, LeBlanc J, Al-Haddad M, et al. Role of endoscopic ultrasound fine-needle aspiration evaluating adrenal gland enlargement or mass. World Journal of Nephrology 2014;3:92-100.

34. Gerke H, Robinson R, Luo P. Diagnosis of focal metastasis to the adrenal gland by EUS-guided core biopsy. Gastrointest Endosc 2005;62:469-471.

35. Haseganu L, Diehl D. Left adrenal gland hemorrhage as a complication of EUS-FNA. Gastrointest Endosc 2009;69:E51-E52.

36. Jhala N, Jhalaa D, Eloubeidi $M$ et al. Endoscopic ultrasoundguided fine-needle aspiration biopsy of the adrenal glands: analysis of 24 patients. Cancer Cytopathology 2004;102:308-314.

37. Puri R, Thandaserry R, Choudhary N, et al. Endoscopic ultrasoundguided fine-needle aspiration of the adrenal glands: analysis of 21 patients. Clin Endosc 2015;48:165-170. 